\title{
INFLUENCE OF PATRINIA SCABIOSIFOLIA ON THE RESISTANCE OF MICE TO WHOLE-BODY VIBRATION
}

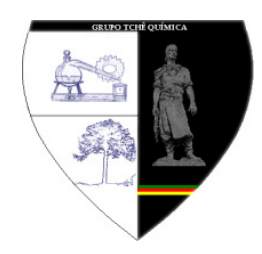

\section{ВЛИЯНИЕ ПАТРИНИИ СКАБИОЗОЛИСТНОЙ НА РЕЗИСТЕНТНОСТЬ МЫШЕЙ К ДЕЙСТВИЮ ОБЩЕЙ ВИБРАЦИИ}

\author{
KHASINA, Eleonora* \\ Federal Scientific Center for Biodiversity of Terrestrial Biota of the Far Eastern Branch of the Russian Academy \\ of Sciences \\ 159, prosp.100-letiya Vladivostoka, Vladivostok 690022, Russian Federation \\ ${ }^{*}$ Corresponding author \\ eleonorakhas@mail.ru
}

Received 14 September 2018; received in revised form 09 October 2018; accepted 09 October 2018

\section{RESUMO}

O objetivo do estudo foi avaliar a eficácia de $P$. scabiosifolia na correção do estado fisiológico e psicossomático de camundongos expostos a vibrações agudas e prolongadas em todo o corpo. $O$ efeito de uma tintura de $40 \%$ água-álcool a partir das raízes de $P$. scabiosifolia foi investigada em camundongos CD-1 sob a influência da vibração de corpo inteiro induzida por um agitador ou exposição ao transporte rodoviário. Componentes emocionais, orientados à exploração e, motor comportamentais foram observados em campo aberto. O desempenho físico foi avaliado pela duração da natação até a fadiga com um peso de $7 \%$ conectado à raiz da cauda. Os índices metabólicos foram corticosterona sérica, glicogênio, lactato e trifosfato de adenosina do fígado e do músculo esquelético. A droga administrada por via oral na dose de $5 \mathrm{ml} / \mathrm{kg}$ otimizou as reações comportamentais dos animais, aumentou seu desempenho no exercício, melhorou o estado hormonal e o metabolismo energético no fígado e músculo esquelético e tecidos sob a influência da vibração do corpo inteiro. A tintura de P. scabiosifolia possui um efeito vibroprotetor e pode ser recomendada para a prevenção e tratamento de distúrbios neurofisiológicos causados por vibração de corpo inteiro, em combinação com terapia básica.

Palavras-chave: PatriniascabiosifoliaFisch. exLink, reações comportamentais, desempenho no exercício, metabolismo, vibração em todo o corpo

\begin{abstract}
The aim of the study was to evaluate the effectiveness of $P$. scabiosifolia in correcting the physiological and psychosomatic state of mice exposed to acute and prolonged whole-body vibration. The effect of a $40 \%$ water-alcohol tincture from the roots of $P$. scabiosifolia was investigated in CD-1 mice under the influence of whole-body vibration induced by a shaker or exposure to road transportation. Emotional, exploratory-oriented and motor behavioral components were observed in the open field. Physical performance was evaluated by the duration of swimming until fatigue with a $7 \%$ weight attached to the tail root. Metabolic indices were serum corticosterone, glycogen, lactate and adenosine triphosphate of the liver and skeletal muscle. The orally administered drug at a dose of $5 \mathrm{ml} / \mathrm{kg}$ optimized the behavioral reactions of the animals, increased their exercise performance, improved hormonal status, and energy metabolism in liver and skeletal muscle and tissues under the influence of whole-body vibration. The $P$. scabiosifolia tincture possesses a vibroprotective effect and can be recommended for the prevention and treatment of neurophysiological disorders caused by whole-body vibration, in combination with basic therapy.
\end{abstract}

Keywords: Patriniascabiosifolia Fisch. exLink .behavioral reactions, exercise performance, metabolism, wholebody vibration 


\section{АННОТАЦИЯ}

Целью исследования была оценка эффрективности п. скабиозолистной в коррекции физиологического и психосоматического состояния мышей, подверженных действию острой и длительной общей вибрации. Эфффект 40\%-ной водно-спиртовой настойки из корней п. скабиозолистной исследовался на мышах линии CD-1 при воздействии общей вибрации, индуцированной шуттельвстряхиванием или дорожно-транспортным воздействием. Эмоциональный, исследовательскоориентировочный и двигательный компоненты поведения мышей наблюдали в «открытом поле». Физическую работоспособность оценивали по длительности плавания животных с 7\%-м грузом на основании хвоста до полного утомления. Метаболическими показателями служили кортикостерон сыворотки крови, гликоген, лактат и аденозинтрифосфат печени и скелетной мышцы. Перорально введенный препарат в дозе 5 мл/кг оптимизировал поведенческие реакции животных, повышал их физическую работоспособность, улучшал гормональный статус и энергетический метаболизм в тканях печени и скелетных мышц и мышей при воздействии общей вибрации. Настойка патринии скабиозолистной обладает вибропротективным действием и может быть рекомендована для профрилактики и лечения нейрофизиологических нарушений, вызванных общей вибрацией, в сочетании с базисной терапией.

Ключевые слова: Patriniascabiosifolia

Fisch. exLink, поведенческие реакции, фризическая работоспособность, метаболизм, вибрация

\section{INTRODUCTION}

Vibration is an extreme factor of the manmade environment, which to some extent accompanies man and animals: vibro-dangerous professional activity and all types of transportation, conditions of industrial livestock. To date, the influence of vibration on the physiological, neuroendocrine, morphological and metabolic levels of the body is fully studied; the concept of 'vibrational stress' and an independent nosological unit 'vibration disease' appeared in practical medicine and veterinary medicine (Babanov et al., 2012). Under vibration stress (the initial and moderately pronounced manifestation of vibration in the early stages of the pathological process), the basic role in the interaction between various systems of the organism is played by the autonomous, peripheral and central nervous systems that trigger the subsequent psychosomatic disturbances (Ivanova, 1991; Ronchese and Bovenzi, 2012).

In spite of the fact a significant amount of measures funds aimed at eliminating various 'aggressive' effects of vibration are developed, fundamental and practical pharmacology aims at searching for and studying the action mechanism of known and recently emerged vibroprotectors (Johanning, 2015). In case of functional disorders of the nervous system and the somatic state of humans and animals, adaptogens, anxiolytics (tranquilizers), plant-derived sedatives (Peeters et al., 2005; Hur and Lee, 2010) are effective in a stressful situation.

The purpose of the study was to evaluate the effectiveness of the tincture of $P$. scabiosifolia, having adaptogenic and sedative action, as a vibroprotective agent.

\section{MATERIALS AND METHODS}

Sexually mature male mice of the CD-1 line (the nursery of the Pacific Institute of Bioorganic Chemistry, FER RAS) with a body weight of $22-25 \mathrm{~g}$ were used in the study. The animals were kept in standard conditions of the vivarium; mixed feed compliant with GOST R 50258-92 (CJSC ProKorm, Russia) and water was supplied without restriction. Each experimental group consisted of 7 animals; each mouse in the cage had a floor area of $70 \mathrm{~cm}^{2}$, which corresponds to international standards. The work was carried out in accordance with the normative documents 'Order of the Ministry of Healthcare of the Russian Federation No. 199n of April 1, 2016 On Approval of the Rules for Appropriate Laboratory Practice' and Directives 2010/63 / EU of the European Parliament and the Council of the European Union for the Protection of Animals used for scientific goals'. The tincture of Patrinia 
scabiosifolia Fisch. ex Link (fam., Caprifoliaceae; TPS) was prepared by maceration from the roots and rhizomes in $40 \%$ ethanol (Vorobieva and Shabanov, 2015). In laboratory experiments, animals received a dealcoholized drug intragastrically at a dose of $5 \mathrm{ml} / \mathrm{kg}$ on an empty stomach in two ways: once an hour before the vibration (1TPS) or for five days preceding it (5TPS). In full-scale experiments, the drug was administered an hour before the road transportation. The animals of the control group and those exposed only to vibration (without the drug) received the equivolume amount of saline.

In laboratory conditions, whole-body vibration was simulated by placing the cell with mice on the platform of the ABU- 6 shaker (oscillation frequency range 120 vibrations $/ \mathrm{min}$, acceleration $1.5 \mathrm{~m} / \mathrm{s}^{2}$, duration of a single exposure $2 \mathrm{hrs}$ ). The noise level created by the shaker was minimal and did not exceed $40 \mathrm{~dB}$ (measured by the NTM-1 sound level meter, Italy).

The state of physiological functions in mice during vibration was estimated by forced swimming test and behavioral activity tests. To determine exercise performance immediately after the two-hour vibration impact, mice were swimming with a $7 \%$ load of its body weight on the tail root until complete exhaustion in an $80 \times$ $60 \times 50 \mathrm{~cm}$ aquarium at a water temperature of $30{ }^{\circ} \mathrm{C}$. Free behavior of the animals was assessed during $3 \mathrm{~min}$ in the open field test (installation 'Open Field', LLC Open Science, Russia) for the following components: horizontal motor activity (HMA; number of crossed arena sectors), vertical motor activity (VMA, standing alone or holding onto the installation wall), grooming (all types of body washing and cleaning), examination of the field holes, and the level of defecation and urination.

Biochemical indices were determined by unified methods: the level of corticosterone in the blood serum was measured spectrofluorometrically, the amount of lactate and adenosine triphosphate (ATP) in the liver and in the skeletal (gastrocnemius) muscle was measured spectrophotometrically (in the test system with nicotinamidedinucleotides NADP and $\mathrm{NAD} \cdot \mathrm{H}$, respectively) and glycogen was measured using an anthrone reagent.

In the field experiment, the mice were subjected to single-day or seven-day road transportation along a highway with a hard surface, covering a distance of $100 \mathrm{~km}$ with an average speed of $50 \mathrm{~km} / \mathrm{h}$. External weather conditions for transportation were as follows: clouds, air temperature $21^{\circ} \mathrm{C}$, air humidity $65 \%$, atmospheric pressure $756 \mathrm{mmHg}$, the noise level on the highway 85-90 dB. Inside the bus cabin the temperature, humidity, the degree of dust and gas contamination corresponded to the norm, the noise level varied within $75-78 \mathrm{~dB}$, the actual equivalent corrected levels of total vibration along the axes were: X-106, Y-105, Z-113 dB. To measure the level of vibration and noise in the cabin during the entire route, an on-site inspection was carried out in the testing laboratory of the Far Eastern Regional Center for Occupational Safety (Vladivostok) with the noise and vibration analyzer "Assistant".

Statistical processing was carried out with the program Statistica, v. 8.0. The significance of the differences between the compared groups was established using the Student's t-test and the one-way ANOVA dispersion analysis. The data in the tables are presented as the mean \pm standard error of the mean $(M \pm m)$.

\section{RESULTS}

A two-hour stay in conditions of general vibration (transmitted through the supporting surfaces of the body) in a shaker caused in mice significant deviations in the body from the physiological norm in such vital functions as metabolism, physical performance, and behavioral responses. Table 1 presents the data on the significant disorders in the hormonemetabolic homeostasis of mice exposed to vibration. The animals showed marked stress, as indicated by the corticosterone level which exceeds the norm by $29 \%$. In accordance with the regulatory role of corticosteroids in the metabolic systems of the body, there are significant deviations in the energy supply of the liver and skeletal muscle in mice under the impact of vibration. Immediately after vibration, these tissues displayed a clear deficit of energy substrates. Thus, the level of ATP and glycogen in the liver was 21 and $22 \%$ below the physiological norm, in the muscle, the indices were 22 and 29\%, respectively. Moreover, both tissues revealed an increased content of lactate 26 and $29 \%$, respectively.

Patrinia, administered once or for five days running (once daily) before the vibration impact significantly minimized the degree of stress without changing the direction of the 
hormonal and metabolic changes in the body (Table 1). The decrease in the level of corticosterone (stress marker) in the blood serum by 13 and $26 \%$ relative to the 'vibration' group (1TPS and 5TPS administered respectively) suggests optimizing the energy supply of the animal organism under the conditions of this unfavorable physical factor. Indeed, the content of ATP, glycogen and lactate in the liver differed from the norm only by 8,6 , and $9 \%$ (1TPS) and 3 , 9 , and $12 \%$ (5TPS), whereas in animals that did not receive the drug the deviations in case of vibration were 21,22 , and $26 \%$, respectively. In skeletal muscle, a higher level of energy reserves was also observed: the difference compared to control in the levels of ATP, glycogen, and lactate was 11,12 , and $9 \%$ (1TPS) and 5,8 , and $14 \%$ (5TPS); in the 'vibration' group the levels were 22 , 29 , and $29 \%$, respectively. The energy-protective effect of Patrinia is directly indicated by the conservation of the resources of ATP and glycogen in the liver and muscle tissues of mice at the optimal level with the simultaneous weakening of acidosis.

The study revealed that vibration significantly reduced the physical efficiency of mice. The duration of swimming time until complete fatigue after vibration was significantly lower than in the animals of the control group - by $31 \%$ (Table 2). The drug administered to the animals in both groups before the vibration increased the endurance during physical exertion by swimming. The endurance of the animals which were given TPS immediately after the exposure to vibration was below the control value only by 15 (1TPS) and 11\% (5TPS); without the drug being administered the level was $31 \%$, which indicates the actoprotective effect of TPS (Table 2).

In a parallel experiment, functional disorders of the nervous system in mice caused by general vibration were revealed. Analysis of motor activity in the open field showed a behavioral change in the animals, indicating their anxious excitement (Table 2). Horizontal motor activity in the open field (jogging through the arena sectors) 3 min after the vibration impact was above the control level by $52 \%$. Vertical motor activity (standing) exceeded the norm by $21 \%$. Acts of grooming (body washing and cleaning) characterizing the emotional state of animals were higher than the control level by $30 \%$. It should be noted that defecation and urination (which are a manifestation of emotions) during the testing of mice in the open field were practically not observed. However, in the cell where the animals were subjected to vibration boluses and wet zones were significantly increased in number than in the control group. The animals' research reaction (peeking into holes and sniffing) in the case of short (3 min) post-vibration testing was not observed, although the number of standing does reflect some research activity, in addition to nonspecific excitability. Patrinia revealed a neuroprotective effect, reducing emotional tension and bringing the correlation of behavioral responses into correspondence (Table 2). The drug is administered, HMA, VMA and grooming acts differed from the norm levels: in the case of 1TPS the levels were 22,11 and $0 \%$, and in the case of 5TPS the levels were 8,15 , and $10 \%$ respectively (in the control group the difference was 52, 21, and $30 \%)$.

In the field experiment, the mice were subjected to single-day or seven-day transportation (vibration combined with an inadequate noise level) along with a highway with a hard surface, covering a distance of $100 \mathrm{~km}$. The physiological state of animals was judged by physical performance - an integral indicator of functional preparation for overcoming the effects of a negative stress factor. After single-day transportation, the ability of mice to swim until fully exhausted was reduced by $31 \%$, and after seven-day transportation by $20 \%$ (Table 3 ). It should be noted that the physical capacity of animals with repeated exposure to vibration and noise is noticeably higher than in single exposure; apparently, there is some adaptation to this combined stressor. Patrinia tincture contributed to slower fatigue while performing intense unavoidable activity: the physical performance of mice in the 'forced swimming' test significantly exceeded the indication of the 'vibration' group subjected to single-day or seven-day transportation (vibration impact) - by 18 and 17\%, respectively (Table 3 ).

\section{DISCUSSION}

The pattern of psychosomatic disorders in mice in the present experiment is consistent with various studies (Yanshina and Liubchenko, 2001; Mazina et al., 2004). Deficiency of ATP, acidosis, and glycogenolysis in the liver and skeletal muscle indicate disruption of adaptivecompensatory capabilities in animals under 
vibration impact. It is known that vibration (both local and general) act in combination with a number of environmental factors and dominates in technogenic conditions of animal life and in all types of transportation (Prisby et al., 2008). Vibroacoustic effect on mice is stressful, as phylogenetically anthropogenic noise and vibration were absent in their vital natural activity. It should be noted that the noise and vibration levels in the cabin of the bus corresponded to the indications for the driver (GOST 12.1.012 - 2004 'SOSS (System of occupational safety standards), Vibration Safety: General Requirements'.

Metabolic and functional disorders in mice due to vibrational impact are a consequence of a neuro-reflex and neurohumoral nature (Toshima and Endo, 2006; Mazina et al., 2004). With excessive excitation of the nervous system, which provokes psychosomatic disorders, anxiolytics, tranquilizers, and sedatives are used (Panossian and Wikman, 2005).

It is known that drugs based on $P$. scabiosifolia possess sedative and adaptive effect and are promising in arresting the excited state of animals (increased anxiety and motor hyperactivity) and, at the same time, disadaptation disorders from internal organs and tissues caused by a stressful situation and used in the treatment of insomnia, anxiety and inflammation of various genesis (Khasina, 2013; Meoli et al., 2005; Zorikova and Khasina, 2005; Zou et al., 2015).

The finding of the present study has shown that tincture $P$. scabiosifolia did not fully eliminate, yet it significantly reduced the degree of psychosomatic disorders in mice after a situational and prolonged vibration impact, apparently through the regulation of the neuroendocrine and metabolic links of the adaptive process.

$P$. scabiosifolia can be vicarious with Valerianaofficinalis since it belongs to the same family of Caprifoliaceae (Hidalgo et al., 2010). It is widespread in the Far Eastern region of the Russian Federation, northern China, Japan, and the Korean peninsula.

\section{CONCLUSIONS:}

The present research revealed that the $P$. scabiosifolia root tincture was efficient in suppressing vibration stress responses in mice.
This vibroprotective effect might be due to increasing duration of physical work until absolute fatigue and normalization of vibration-related behavioral alterations. This drug has increased the nonspecific resistance of mice to whole-body vibration by energy-saving effect at the expense of hindrance of exhaustion of glycogen and adenosine triphosphate reserves in the liver and skeletal muscle and optimization hormonal status of animals.

The findings of the present study indicate that $P$. scabiosifolia root tincture is promising as a preventive remedy for increasing the non-specific resistance of animals and human to whole-body vibration.

\section{REFERENCES:}

1. Babanov, S. A.; Vakurova, N. B.; Azovskova, T. A.; Vibration disease. Optimization of diagnostic and therapeutic interventions, Ofort: Samara, 2012.

2. Hidalgo, O.; Mathez, J.; Garcia, S.; Genome size study in the Valerianaceae: first results and new hypotheses; $J$. Botany 2010. ID 797246.

3. Hur, J. W.; Lee, J. Y.; Effects of chronic vibration stress on liver, kidney and testes of the soft-shelled turtle Pelodiscussinensis; J. Appl. Anim. Res. 2010, 37(2), 241.

4. Ivanova, L. A., ed.; Technology of medicinal forms, Medicine 1991, 2, 364.

5. Johanning, E.; Whole-body vibrationrelated health disorders in occupational medicine - an international comparison; Ergonomics 2015, 58(7), 1239.

6. Khasina, E. I.; Correction of the stressreaction of mice on intensive noise with Patrinia scabiosifolia tincture; Newletter of the Samara Scientific Centre of the RAS 2013, 15, 3(6), 1980.

7. Mazina, N. K.; Vorobieva, V. V.; Alexeeva, O. A.; Babin, A. P.; Influence of energy metabolism regulators on the rats physical endurance damaged by general vibration (experimental research); Medical Newsletter of Vyatka 2004, 1, 11.

8. Meoli, A. L.; Rosen, C.; Kristo, D.; Oral nonprescription treatment for insomnia: an evolution of products with limited evidence; J. Clin. Sleep Med. 2005, 1(2), 173. 
9. Mohammadzadeh, S.; Karimian, $\mathrm{H}_{\text {; }}$; Khosra, H.; Shahbazi, F.; Effect of different mechanical vibration on blood parameters of one day old broiler chicken; Anim. Res. Int. 2015, 12(1), 2143.

10. Pankov, V. A.; Kuleshova, M. V.; Katamanova, E. V.; Kartapoltseva, N. V.; Vibration influence on functional activity of nervous system in experimental animals; Bulletin of East Siberian Scientific Center SB RAMS 2013, 3 (2), 113.

11. Panossian, A.; Wikman, G.; Effect of adaptogens on central nervous system; Arquiv. Brasil. Fitomed. Cientifica 2005, 3(1), 29.

12. Peeters, E.; Neyt, A.; Beckers, F.; Influence of supplemental magnesium, tryptophan, vitamin $\mathrm{C}$ and vitamin $\mathrm{E}$ on stress responses of pigs to vibration; $J$. Anim. Sci. 2005, 83(7), 1568.

13. Prisby, R. D.; Lafage-Proust, M.; Malaval, L.; Effect of whole body vibration on the skeleton and other organ systems in man and animal models: what we know and what we need to know; Ageing Res. Rev. 2008, 7, 319.

14. Ronchese, F.; Bovenzi, M.; Occupational risk and health disorders in transport drivers; G. Ital. Med. Lav. Ergon. 2012, 34(3), 352.

15. Toshima, H.; Endo, Y.; Effect of whole- body vibration on autonomic nervous system; Autonom. Neurosci. Basic Clin. 2006, 130(1), 65.

16. Ubeeva, I. P.; Tsibikova, E. N.; Rasuvaeva, Y. G.; Phytocorrection of diseases of nervous system (literature review); Bulletin of Buryat State University 2013, $12,7$.

17. Ushkalova, A. B.; Illarionova, T. S.; Efficiency and safety of herbal antidepressant and sedative remedies; Pharmateca 2007, 20(154), 10.

18. Vorobieva, V. V.; Shabanov, P. L.; Vibration and vibroprotectors (Pharmacology of extreme state: in 12 volumes. Vol. 6), Inform Navigator: St.Petersburg, 2015.

19. Yanshina, E. N.; Liubchenko, P. N.; Phsychoemotional disorders in vibration disease; Occupational medicine and industrial ecology 2001, 2, 32.

20. Zorikova, O. G.; Khasina, E. I.; Patrinia scabiosifolia; Dalnauka: Vladivostok, 2005.

21. Zou, W.; Wen, X.; Zheng, Y.; Metabolic study on preventive effect of Patrinia scabiosaefolia Fisch. On multipathogen induced pelvic inflammatory disease in rats; Evidence-based Complem. Altern. Med. 2015. ID 170792. 
Table 1. Influence of the tincture of $P$. scabiosifolia (TPS) on hormone-energy metabolism in mice under vibration

\begin{tabular}{l|l|l|l|c}
\hline \multirow{2}{*}{ Parameter } & \multicolumn{4}{c}{ Group of animals } \\
\cline { 2 - 5 } & control & vibration & $\begin{array}{c}\text { vibration }+ \\
\text { 1TPS }\end{array}$ & $\begin{array}{c}\text { vibration + } \\
\text { 5TPS }\end{array}$ \\
\hline $\begin{array}{l}\text { Corticosterone, } \mu \mathrm{mol} / \mathrm{L} \\
\text { ATP, } \mu \mathrm{mol} / \mathrm{g}\end{array}$ & $0,31 \pm 0,02$ & $0,40 \pm 0,02^{*}$ & $0,35 \pm 0,02$ & $0,32 \pm 0,01^{* *}$ \\
liver & & & & \\
muscle & $3,36 \pm 0,07$ & $2,65 \pm 0,12^{*}$ & $3,08 \pm 0,05^{\star *}$ & $3,26 \pm 0,07^{* *}$ \\
$\begin{array}{l}\text { Glycogen, } \mu \mathrm{mol} / \mathrm{g} \\
\text { liver }\end{array}$ & $4,40 \pm 0,09$ & $3,45 \pm 0,13^{*}$ & $3,93 \pm 0,07^{* *}$ & $4,17 \pm 0,10^{* *}$ \\
muscle & $234,2 \pm 11,1$ & $181,8 \pm 7,6^{*}$ & $220,2 \pm 14,4^{* *}$ & $213,5 \pm 10,1^{* *}$ \\
Lactate, $\mu \mathrm{mol} / \mathrm{g}$ & $23,5 \pm 1,23$ & $16,6 \pm 1,04^{*}$ & $20,6 \pm 0,71^{* *}$ & $21,6 \pm 0,74^{* *}$ \\
liver & & & & \\
muscle & $2,40 \pm 0,09$ & $3,02 \pm 0,10^{*}$ & $2,51 \pm 0,17^{* *}$ & $2,68 \pm 0,10^{* *}$ \\
\hline
\end{tabular}

Note: ATP - adenosine triphosphate; 1TPS - one-time introduction 1 hour before the vibration; 5TPS an introduction for 5 days prior the vibration (once daily, on an empty stomach). ${ }^{*}-\mathrm{P}<0.05$ - compared with the 'control' group; ** - $\mathrm{P}<0 / 05$-compared with the 'vibration' group.

Table 2. Influence of TPS on exercise performance and behavioral reactions of mice under the influence of whole-body vibration

\begin{tabular}{l|lr|c|c|c}
\hline \multirow{2}{*}{$\begin{array}{l}\text { Group of } \\
\text { animals }\end{array}$} & \multicolumn{2}{|c|}{$\begin{array}{c}\text { Exercise } \\
\text { performance }\end{array}$} & \multicolumn{3}{c}{ Locomotor activity acts } \\
\cline { 2 - 6 } & min & $\%$ & HMA & VMA & Grooming \\
\hline control & $20,4 \pm 1,57$ & 100 & $25,7 \pm 2,40$ & $7,57 \pm 0,48$ & $2,86 \pm 0,26$ \\
vibration & $14,0 \pm 1,45^{*}$ & 69 & $38,9 \pm 2,80^{*}$ & $9,14 \pm 0,51^{*}$ & $3,71 \pm 0,28^{*}$ \\
vibration +1TPS & $17,4 \pm 0,10$ & 85 & $31,3 \pm 1,41^{* *}$ & $8,43 \pm 0,37$ & $2,85 \pm 0,26^{* *}$ \\
vibration +5TPS & $18,1 \pm 1,02^{* *}$ & 89 & $27,6 \pm 2,59^{* *}$ & $8,71 \pm 0,47$ & $3,14 \pm 0,26$ \\
\hline
\end{tabular}

Note: HMA - horizontal motor activity; VMA - vertical motor activity; 1TPS - the one-time introduction of Patrinia tincture; 5TPS - five-time one-time introduction of Patrinia tincture. ${ }^{*}-\mathrm{P}<0.05-$ compared with the 'control' group, ${ }^{* *}-\mathrm{P}<0.05-$ compared with the 'vibration' group.

Table 3. Influence of the TPS on the exercise performance of mice under the influence of road transportation

\begin{tabular}{c|c|c|c|c}
\hline \multirow{2}{*}{$\begin{array}{c}\text { Group of } \\
\text { animals }\end{array}$} & \multicolumn{4}{|c}{ Road transportation } \\
\cline { 2 - 5 } & min & $\%$ & min & $\%$ \\
\hline control & $22.8 \pm 1.3$ & 100 & $19.4 \pm 1.1$ & 100 \\
vibration & $15.8 \pm 1.2^{*}$ & 69 & $15.6 \pm 0.9^{*}$ & 80 \\
vibration+TPS & $19.8 \pm 1.3^{* *}$ & 87 & $18.9 \pm 0.9^{* *}$ & 97 \\
\hline
\end{tabular}

Note: TPS - tincture of $P$. scabiosifolia, ${ }^{*}-\mathrm{P}<0.05$ - compared with the 'control' group, ${ }^{* \star}-\mathrm{P}<0.05-$ compared with the 'vibration' group. 